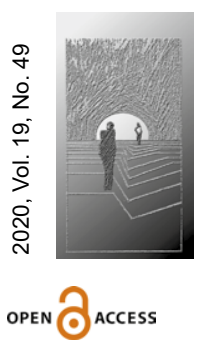

Anna Ryłko-Kurpiewska

http://orcid.org/0000-0002-5435-6577

Uniwersytet Gdański

maria.rylko-kurpiewska@ug.edu.pl

DOI: $10.35765 / h w .1837$

\title{
Rodzina skonstruowana na potrzeby perswazji w świetle badań reklamy i znaków towarowych
}

\section{STRESZCZENIE}

CEL NAUKOWY: Celem artykułu jest ukazanie zależności pomiędzy obrazem rodziny w języku a działaniami kreacyjnymi $w$ reklamie oraz przedstawienie aktualnego obrazu rodziny $w$ działaniach reklamowych na podstawie analizy znaków towarowych i badań reklamy telewizyjnej.

PROBLEM I METODY BADAWCZE: Problemem badawczym jest ukazanie sposobów przedstawiania rodziny $w$ reklamie przy równoczesnym wskazaniu przyczyn dokonywanych na potrzeby perswazji wyborów. Spośród metod badawczych zastosowano analizę danych słownikowych, analizę korpusową, badania potencjału perswazyjnego znaków, ramowanie (frame semantics) oraz pomocniczo metodologię językowego obrazu świata.

PROCES WYWODU: Wywód składa się z trzech części. Celem pierwszej części jest ukazanie specyfiki słowa i pojęcia rodziny w języku w świetle badań korpusowych i słownikowych, które ukazują przyczyny sposobów przedstawiania rodziny w reklamie. W dalszej części rozważań ukazano sposoby eksploatacji pojęcia rodziny w projektowaniu znaków towarowych. Trzecia część wywodu skupia się na zaprezentowaniu specyfiki prezentacji rodziny i jej modelu w reklamie komercyjnej.

WYNIKI ANALIZY NAUKOWEJ: Przeprowadzone badania dowodzą, że sposób przedstawienia rodziny w reklamie telewizyjnej odpowiada najbardziej popularnym słownikowym i korpusowym znaczeniom, które uzasadniają wybór rodziny nuklearnej w reklamie w zastępstwie rodziny wielopokoleniowej. Obraz rodziny w spotach i znakach towarowych służy realizacji funkcji fatycznej, wartościowaniu produktów, oferty lub producenta i wykorzystuje heurystyki, służąc przyjęciu przez odbiorcę sądów wyrażanych w komunikatach.

WNIOSKI, INNOWACJE, REKOMENDACJE: Obraz rodziny w znakach towarowych i reklamach telewizyjnych jest mniej zróżnicowany w zestawieniu z przekazami medialnymi o innej niż perswazyjna funkcji. Różni się także od obrazu rodziny w reklamach właściwych dla przestrzeni Internetu. Wykorzystanie tradycyjnego znaczenia rodziny utrwalonego w języku i myśleniu potocznym jest modyfikowane w zależności od potrzeb zaplanowanego adresata (matki, ojca, ich potomstwa), co otwiera dyskusję nad zmieniającymi się wzorcami męskości, kobiecości i dziecięcości.

$\rightarrow$ SŁOWA KLUCZOWE: RODZINA, ZNAKI SŁOWNO-GRAFICZNE, REKLAMA TELEWIZYJNA, SPOŁECZEŃSTWO 


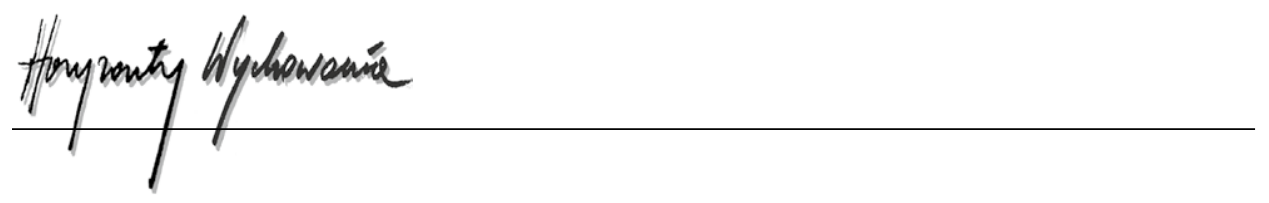

\begin{abstract}
The Family Constructed for the Purpose of Persuasion in the Light of Advertising and Trademark Research
\end{abstract}

RESEARCH OBJECTIVE: The purpose of the article is to show the relationship between the image of the family in language and creative activities in advertising, and to present the current image of the family in advertising activities based on trademark analysis and television advertising research.

THE RESEARCH PROBLEM AND METHODS: The research problem is to show how to present the family in advertising while indicating the reasons for persuasion. Among the research methods, the dictionary data analysis, corpus analysis, potential tests, frame semantics and, as an alternative, a linguistic image of the world were chosen.

THE PROCESS OF ARGUMENTATION: The argument consists of three parts. The purpose of the first part is to show the specifics of the word and concept of the family in language in the light of corpus and dictionary studies, which show the reasons for the ways of presenting the family in advertising. The rest of the discussion presents ways of using the concept of the family in the design of trademarks. The third part of the discussion focuses on showing the specifics of presenting the family and its model in commercial advertising.

RESEARCH RESULTS: The conducted research proves that the way the family is presented in television advertising corresponds to the most popular dictionary and corpus meanings that justify the choice of a nuclear family in advertising instead of a multi-generational family. The image of a family in spots and trademarks serves the purpose of performing a fatal function, evaluating products, an offer or a producer, and uses heuristics to serve the recipient's acceptance of the judgements expressed in the messages.

CONCLUSIONS, INNOVATIONS, AND RECOMMENDATIONS: The image of the family in trademarks and TV commercials is less diverse when combined with media messages of a nonpersuasive function. It also differs from the family image in Internet-specific ads. The use of the traditional meaning of the family fixed in language and colloquial thinking is modified to the needs of the intended addressee (mother, father, their offspring), which opens the discussion on the changing patterns of masculinity, femininity and childhood.

$\rightarrow$ KEYWORDS: FAMILY, WORD AND GRAPHIC CHARACTERS, TELEVISION ADVERTISING, SOCIETY

\title{
Wprowadzenie
}

Wybór bohatera reklamy jest zasadniczą kwestią z punktu widzenia celów przekazu perswazyjnego i jego efektywności. $Z$ tego też powodu galerię postaci reklamowych tworzą niejednokrotnie bohaterowie mający zjednywać sobie sympatię lub aprobatę, 
podobni do zaplanowanego odbiorcy lub osób z jego najbliższego otoczenia. Wzorów takich postaci dostarcza rodzina nuklearna (lub kreacje ją imitujące), stanowiąca obecnie najczęstszy typ odniesień w reklamie komercyjnej, która - w przeciwieństwie do lat ubiegłych - bardzo rzadko eksponuje typ rodziny wielopokoleniowej (Dybalska, 1998, s. 15). Analogiczną sytuację można odnotować w obszarze znaków towarowych, czerpiących swój potencjał z myślenia potocznego i dostosowywanych do sposobów wartościowania odbiorcy. Inspiracji dla tych aktywności można poszukiwać w działaniach językowych, które odzwierciedlają postrzeganie rodziny jako słowa i pojęcia oraz wyjaśniają powody, dla których prezentowane niegdyś w reklamie wzorce mężczyzn i kobiet (Oparski, 1998, s. 35) musiały ulec zmianie. Celem artykułu jest ukazanie zależności pomiędzy obrazem rodziny w języku a aktualnymi działaniami kreacyjnymi w reklamie na podstawie analizy znaków towarowych i badań reklamy telewizyjnej. Jako problem badawczy wybrano określenie sposobów przedstawiania rodziny w reklamie i wyjaśnienie przyczyn dokonywanych na potrzeby perswazji wyborów oraz sposobów eksploatacji.

\section{Metody i narzędzia badawcze}

Metody i narzędzia badawcze dostosowano do podejmowanych problemów oraz materiału, co dyktowało sposób i zakres korzystania z przedstawianych metodologii. Badania słowa i pojęcia 'rodzina' dokonano na podstawie znaczeń utrwalonych w słownikach języka polskiego, analizy korpusowej oraz pomocniczo metodologii językowego obrazu świata. Specyfikę znaków towarowych przedstawiono na podstawie badania potencjału perswazyjnego nazw i znaków słowno-graficznych. Natomiast do analizy reklam telewizyjnych wykorzystano lingwistyczne ujęcie ramowania - frame semantics (Fillmore, 1976, s. 20, 25; 1982, s. 111), gdzie rozpatrywanie danych „łączy się z reprezentacją wiedzy oraz konstruowaniem znaczeń językowych widzianych przez pryzmat funkcjonowania umysłu i różnych typów pamięci” (Ryłko-Kurpiewska, 2016, s. 187).

Głównymi problemami badawczymi były pytania: o obraz znaczeń rodziny we współczesnym języku polskim przy uwzględnieniu znaczeń diachronicznych, specyfikę wyobrażeń rodziny w zarejestrowanych znakach towarowych oraz model rodziny i sposób jej wyobrażenia w reklamie telewizyjnej. Materiał badawczy stanowiły 833 reklamy wyekscerpowane ze zbioru 7147 przekazów emitowanych w telewizji Polsat w okresie od 1 grudnia 2018 do 30 listopada 2019 r., pochodzące z monitoringu Kantar Media oraz materiały archiwalne zebrane przez autorkę w celach porównawczych. Badanie liczby przekazów wykazało porównywalne z latami ubiegłymi (2016-2018) przedstawienie obrazów rodziny, które stanowiły 12-13\% wszystkich reklam w badanej stacji. W gromadzeniu materiału zastosowano wybór celowy, który odpowiadał podejmowanej problematyce. 


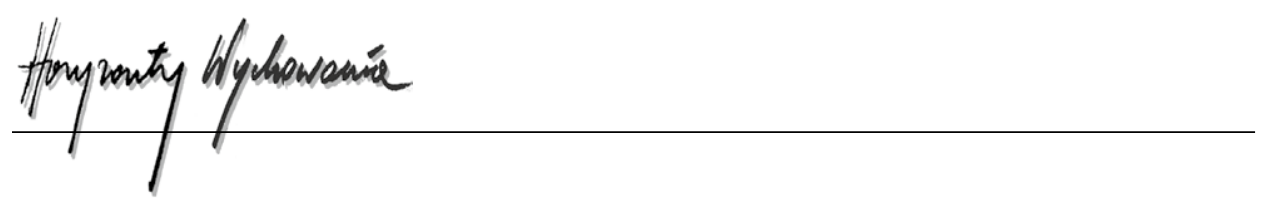

\section{Pojęcie rodziny w języku}

Analiza pojęcia rodziny jako konstruktu myślowego w języku dostarcza wielu obserwacji dotyczących wyboru znaczeń przypisywanych mu na gruncie reklamy. Punktem wyjścia do rozważań mogą tu być słowniki języka polskiego oraz elektroniczne korpusy języka polskiego ukazujące synchroniczne i diachroniczne aspekty funkcjonowania słów (jako materialnej formy pojęć) oraz językową przestrzeń do ich eksploatacji w różnych rejestrach języka. Rodzina w słownikach języka polskiego to w pierwszej kolejności wspólnota, składająca się z rodziców i potomstwa, podstawowa grupa społeczna, cechująca się więzią emocjonalną i formalną, zależnością materialną i mieszkaniową oraz zespołem funkcji. Rodzina to również osoby związane pokrewieństwem lub powinowactwem (Dubisz, 2003, t. 3, s. 962; 2018, t. 4, s. 106; Markowski, 2001, s. 973; Szymczak, 1881; Żmigrodzki, 2018), co wynika z prasłowiańskiej etymologii słowa 'rodina' ('to, co związane z rodem', 'pokrewieństwo', 'spokrewnione osoby; członkowie tego samego rodu', 'ziemia rodowa'), pochodzącego od prasłowiańskiego *rodъ - ród, plemię, oznaczającego od XIV w. osoby pochodzące od wspólnego przodka (Boryś, 2005, s. 516, 524). Słowo to stało się również przyczyną powstania w języku polskim rzeczowników 'rodzic' (oznaczającego członka należącego do tego samego rodu) oraz 'rodzica' (krewna należąca do tego samego rodu), które w miarę upływu czasu zyskały nowe znaczenia. W XV w. 'rodzica' to rzeczownik utworzony od czasownika 'rodzić' w znaczeniu matka, rodzicielka. Natomiast 'rodzic' jako ojciec jest datowany na wiek XVII i stanowi formę wtórną od wyrazu 'rodzice' (Kreja, 2001, s. 85, 86).

Interesujące wydaje się, że funkcjonowanie słów „rodzina” czy „rodzic” jest współcześnie właściwe różnym rejestrom polszczyzny i pojawia się w różnych kontekstach. Z danych korpusowych wyekscerpowanych z Narodowego Korpusu Języka Polskiego w wersji zrównoważonej (http://www.nkjp.uni.lodz.pl; dostęp: 10.12.2019) wynika, że słowo 'rodzina' najczęściej pojawia się w literaturze pięknej, głównie w poezji oraz codziennej prasie, a słowo 'rodzic' w tekstach informacyjno-poradnikowych i w ilustrowanych miesięcznikach, gdzie jako pierwszy na liście wszystkich kolokatów sytuuje się rodzic samotny (w liczbie mnogiej jest to wyrażenie przybrani rodzice).

Współczesne postrzeganie rodziny w polszczyźnie ostatnich lat z całą pewnością ulega zmianom, jednakże na pierwszy plan nadal wysuwają się tu znaczenia już utrwalone w języku. Sytuację tę obrazują badania statystyk współwystąpień w wyszukiwarkach MONCO.pl (http://monco.frazeo.pl/, dostęp: 17.12.2019) i PELCRA (http://www.nkjp. uni.lodz.pl/collocations.jsp; dostęp: 20.12.2019), gdzie rodzina to najczęściej tradycyjna wspólnota (również całość) złożona z członków, które wiążą cechy bliskiego pokrewieństwa, składająca się z dwojga rodziców i dwojga dzieci (por. notowane na 3. miejscu wyrażenie „rodzina czteroosobowa” - Chi^2 36 151, 379.36), czy rzadziej dwojga rodziców i trojga dzieci (por. notowane na miejscu 5. wyrażenie „rodzina pięcioosobowa" - Chi^2 55, 362.13). Rodzina w korpusach to również wspólnota tworzona przez jednego lub dwóch opiekunów, sprawujących opiekę nad małoletnim dzieckiem lub dziećmi w zastępstwie rodziców biologicznych (por. notowane na miejscu 4. wyrażenie 
„rodzina zastępcza” - Chi^2 6358, 606.63), co wprowadza rzadziej notowane w słownikach językowych znaczenie kontekstowe słowa oparte na parafrazie: przyjęty do rodu i niezwiązany pokrewieństwem. Wśród najczęstszych współwystąpień uwagę zwracają również kolokacje odnoszące się do relacji lokacyjnych i temporalnych związanych z miejscem, skąd pochodzi jednostka (rodzina mieszka, rodzina mieszkała), relacjach zewnętrznego otoczenia względem rodziny jako całości (kolokacja 'program rodzina' zawierająca presupozycję „dla” w odniesieniu do strategii miejskiej polityki rodzinnej) lub podkreślających egocentryczny charakter postrzegania samej wspólnoty (przyjaciel rodziny, bliska rodzina). Tę perspektywę postrzegania świata od wewnątrz w stosunku do świata zewnętrznego (Handke, 2008, s. 100) podkreślają też inni badacze, którzy do opisu pojęcia rodziny wykorzystują metodologię językowego obrazu świata.

Warto zauważyć, że wnioski wynikające z analizy znaczeń przypisywanych słowu „rodzina” w słownikach językowych i danych korpusowych jasno wskazują na dominację utrwalonych znaczeń pojęcia odpowiadających jego tradycyjnemu rozumieniu, które funkcjonuje w aktach prawnych (por. Konstytucję Rzeczypospolitej Polskiej z dnia 2 kwietnia 1997 r., Dz.U. 1997 Nr 78, poz. 483 ze zm., gdzie rodzina to małżeństwo kobiety i mężczyzny i rodzicielstwo, oraz zawierającą analogiczną definicję rodziny Ustawę z dnia 25 lutego 1964 r. - Kodeks rodzinny i opiekuńczy, Dz.U. z 2015 r., poz. 2082, art. 146) i innych dokumentów, będących punktem odniesienia dla opracowania ustawodawstwa i polityki rodzinnej (por. także Karta Praw Rodziny przedłożona przez Stolicę Apostolską). Dane językowe pochodzące ze słowników i korpusów języka polskiego ściśle korespondują z badaniami opinii społecznej przeprowadzonymi w 2019 r. przez Centrum Badania Opinii Społecznej, gdzie respondenci definiowali rodzinę przede wszystkim jako grupę dwupokoleniową złożoną z małżonków i dzieci (99\% wskazań), a rzadziej jako matkę czy ojca samotnie wychowujących przynajmniej jedno dziecko (91\% wskazań), osoby pozostające w związku nieformalnym i wychowujące dzieci z tego związku (83\% wskazań), osoby żyjące w konkubinacie (78\%), osoby wspólnie wychowujące dzieci z poprzednich związków oraz osoby wspólnie zamieszkujące, ale nieposiadające dzieci (65\%). Zdecydowanie rzadziej jako rodzina były definiowane inne nieformalne związki (https://www.cbos.pl > SPISKOM.POL > 2019; dostęp: 8.01.2020).

Wyobrażenia rodziny obecne w danych językowych oraz opiniach społecznych ściśle korespondują z obrazem rodziny w reklamie telewizyjnej (niekiedy w opozycji do wizerunków rodziny kreślonych przez inne medialne przekazy: blogosferę, serwisy internetowe typu YouTube), która czerpiąc z systemu pojęć wykształconego przez polskie społeczeństwo, używa ich w celach perswazyjnych, zgodnie ze znaną w komunikacji zasadą wspólnego gruntu (Kurcz, 2000, s. 136-137), stanowiącego podstawę efektywnego przebiegu działań reklamowych, jeszcze przed przeprowadzaniem badań poprzedzających emisję reklamy. 


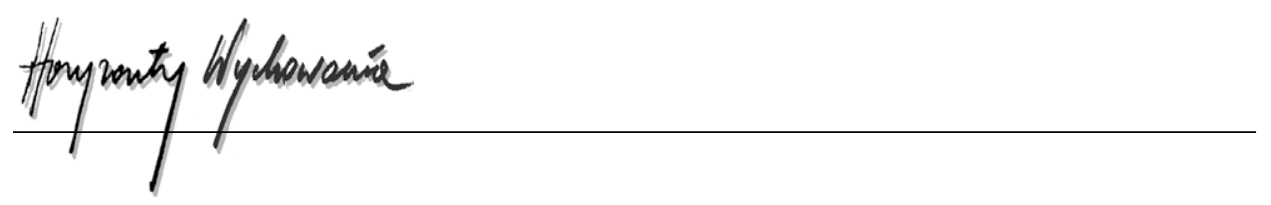

\section{Pojęcie rodziny i specyfika znaków towarowych}

Wspólna wiedza wraz z utrwalonym potencjałem konotacyjnym to obok potrzeb i oczekiwań konsumentów niezwykle istotny czynnik w kontekście kreacji reklamy. Nic więc dziwnego, że popularne konstrukty myślowe w działaniach reklamowych zostają zestawione z priorytetowymi dla adresatów wartościami. Wśród nich rodzina zajmuje miejsce szczególne, według badań CBOS z 2019 r. jest ona bowiem wartością najwyższą i podstawowym gwarantem szczęścia (opinię taką wyraża 80\% Polaków, podczas gdy $87 \%$ respondentów uważa, że do pełni szczęścia potrzebuje rodziny). Kolejne miejsca na liście wartości preferowanych przez polskie społeczeństwo zajmują zdrowie (55\%), spokój (48\%) i grono przyjaciół (45\%).

Wyobrażenie rodziny w polszczyźnie i myśleniu potocznym to rodzina mała, dwupokoleniowa, składająca się z dwojga rodziców i dwojga dzieci, których łączą wskazywane na gruncie psychologii różne typy relacji (wybór za: Jachnis i Terelak, 1998, s. 292). W myśleniu potocznym na plan pierwszy wysuwają się więzi emocjonalno-ekspresyjne (por. fraz. bliska rodzina, najbliższa rodzina, moja rodzina, kochająca się rodzina, dobra rodzina, szczęśliwa rodzina, rodzina matriarchalna), prokreacyjne (matka rodzicielka), socjalizacyjno-wychowawcze (rodzina patriarchalna) i materialno-ekonomiczne (głowa rodziny). Obraz tych relacji znajduje odzwierciedlenie w zależności od typu działań reklamowych, co można zobrazować na przykładzie znaków towarowych zarejestrowanych w Urzędzie Patentowym Rzeczpospolitej Polskiej (grupa 192 znaków ${ }^{1}$ ) oraz wybranych reklam telewizyjnych, stanowiących najbardziej liczny i reprezentatywny zbiór obrazu rodziny w reklamie.

W tworzeniu znaków słowno-graficznych i słownych wykorzystuje się najczęściej wyobrażenie rodziny nuklearnej oraz łączące ją więzi emocjonalno-ekspresyjne i materialno-ekonomiczne. Ich wyobrażenie w znakach towarowych ma charakter sugestywno-wyobrażeniowy lub opisowy, aspirujący do miana znaków wyobrażeniowych (por. Zboralski, 1995, s. 114) i pełni najczęściej funkcje wartościowania działań nadawcy (działalność dla rodzin) przy wykorzystaniu wyobrażonych portretów odbiorcy (dla 55\% Polaków niezmiennie od 2013 do 2019 r. najbardziej pożądanym modelem rodziny jest rodzina mała, a 49\% Polaków taką rodzinę tworzy; CBOS, 2019), co ma się łączyć z wartościowaniem postawy odbiorcy oraz promowanych przez znak produktów i usług. Sytuację tę dobrze obrazują również reklamowe slogany (por. hasło hipermarketu Tesco - „Dla Ciebie, dla Rodziny” czy nazwy oferty ubezpieczeń „Warta dla Ciebie i Rodziny”), które wartościując nadawcę jako darczyńcę, wyróżniają też adresata (por. funkcję przyimka dla) jako osobę dbającą o rodzinę.

Wśród znaków poddanych badaniu na plan pierwszy wysuwają się wyroby farmaceutyczne (grupa 84 znaków), gdzie obok wartości rodzinnych wskazuje się na zdrowie

\footnotetext{
${ }^{1}$ Badanie przeprowadzono za pomoca wyszukiwarki Register Plus dla znaków towarowych. Źródło: regservtd. uprp.pl/register/advancedSearch?searchMode=advanced\&pn=\&ap $=\& f d=\& p d=\&$ prd $=\& p a=\& r e=\& i n=\& p r=\&$ ti $=$ rodzina\&op $=\& i c=($ dostęp: 17.12 .2019$)$.
} 
(por. nazwy: ZDROWA RODZINA, Zdrowa Rodzina Polopiryna, Rodzina Zdrowia, Fervex Zdrowa Rodzina) jako drugą z preferowanych przez Polaków wartości (por. CBOS, 2019). Dużą grupę (67) stanowią też znaki promujące działalność usługową świadczoną przez osoby lub instytucje. Wśród nich uwagę zwracają logotypy podmiotów prowadzących sprzedaż hurtową i detaliczną produktów z różnych sektorów (por. ryc. 1-2 przedstawiające znaki słowno-graficzne: spółki Saro czy spółki BIOVICO), gdzie różnorodność oferty ma się odnosić do zróżnicowanych potrzeb zarówno poszczególnych członków rodziny, jak i rodziny jako całości.

Rycina 1. Logotyp spółki Saro

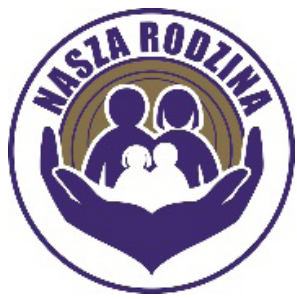

Rycina 2. Logotyp spółki BIOVICO

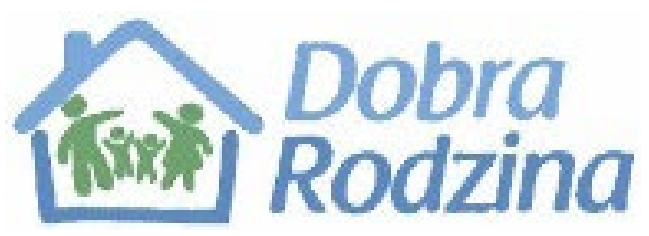

Źródło (1): https://regservtd.uprp.pl/register/application?number=Z.495443 (dostęp: 17.12.2019). Źródło (2): https://regservtd.uprp.pl/register/application?number=Z.359769) (dostęp: 17.12.2019).

Słowne lub słowno-graficzne wyobrażenie rodziny pojawia się również w znakach zarejestrowanych w klasie kosmetyków i preparatów oraz artykułów higienicznych (por. logotyp Nivea Bambino Rodzina przedstawiony na ryc. 3), produktów mlecznych (Wesoła Rodzina), telefonii komórkowej (por. ryc. 5-7 Rodzina, Formuła Rodzina), usług w zakresie pośrednictwa w sprzedaży nieruchomości i usług budowlanych czy usług ubezpieczeniowych (Rodzina 2000, Profit Rodzina, Bezpieczna Rodzina).

Rycina 3. Logotyp NIVEA

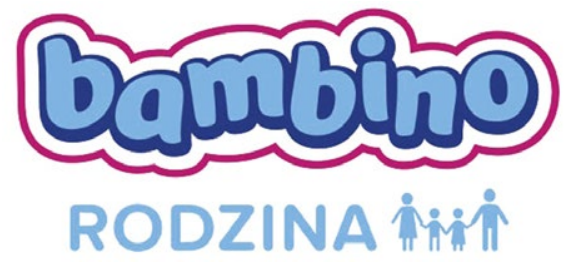

Rycina 4. Logotyp ABN Nieruchomości

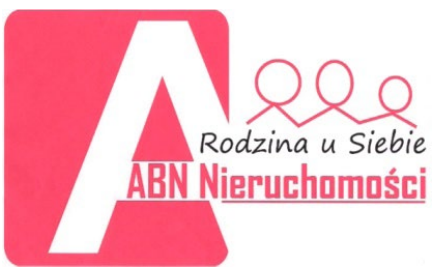

Źródło (3): https://regservtd.uprp.pl/register/application?number=Z.478838 (dostęp: 17.12.2019). Źródło (4): https://regservtd.uprp.pl/register/application?number=Z.44656 (dostęp: 17. 12.2019). 


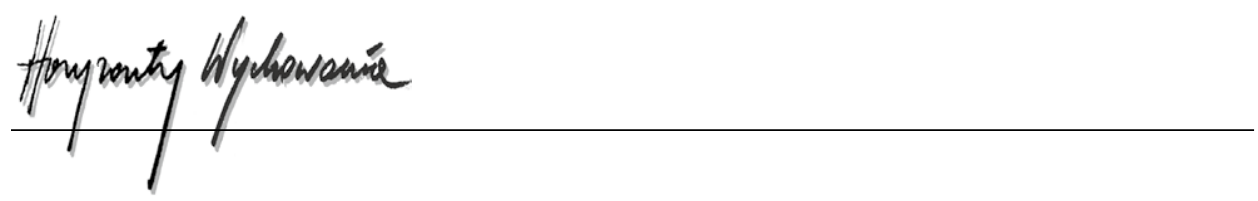

Ryciny 5-7. Znaki PLAY.

\section{FORMULA} RODZINA

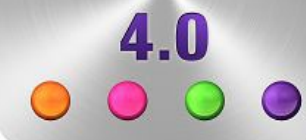

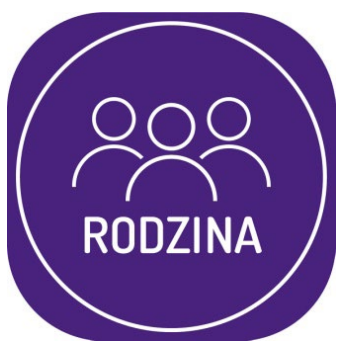

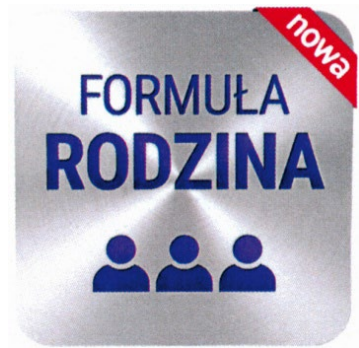

Źródła https://regservtd.uprp.pl/register/application?number=Z.426735 https://regservtd.uprp.pl/register/application?number=Z.457435 https://regservtd.uprp.pl/register/application?number=Z.489648 2018 (dostęp: 17.12.2019).

Wśród prezentowanych na rycinach znaków szczególną uwagę zwraca znak sugestywno-wyobrażeniowy Bambino Rodzina, który odwołuje się do więzi emocjonalno-ekspresyjnych przez zastosowanie schematu dziecięcości. Znaczenia zawarte w przekazie słownym (por. znaczenie słowa bambino w języku włoskim) zostają wzmocnione szczególnie dzięki typografii wyzwalającej w konsumencie chęć opieki nad dzieckiem. Wrażenie to wynika zarówno z projektu poszczególnych liter (por. m.in. długość wydłużenia górnego $w$ literze b, odnosząca się do zaburzonych proporcji ciała u niemowlęcia), jak iz maksymalnej redukcji świateł międzyliterowych oraz zmiany konturu linii bazowej przy małej amplitudzie ruchów, przywołujących nieporadne ruchy małego dziecka. Znak ten wyróżnia się na tle pozostałych również wyrazistością i czytelnością uzyskaną za sprawą kroju złożonego z obrysu liter (outline) i wyboru świateł litery (por. oko zamknięte $w$ literach $b, a, o$ ). Jego naczelną wartością jest jednak nastawienie na relację z odbiorcą zgodną z konstruktem więzi między rodzicami a potomstwem, której brakuje (choć w różnym stopniu) wszystkim pozostałym znakom. Jako przykład można wskazać znak Rodzina u Siebie, gdzie brak rytmu w rysunku postaci sprawia wrażenie dezintegracji, a funkcjonujący w warstwie werbalnej zaimek dzierżawczy przywołuje stałe połączenia frazeologiczne (grać na siebie, zadbać o siebie, byt dla siebie), prowadząc ku indywidualistycznemu, a nie personalistycznemu (nastawionemu na relacje) odczytaniu znaku, przez co zaburza postrzeganie wytypowanego do projektu wyobrażenia rodziny małej.

Logotopy: Nasza Rodzina, Dobra Rodzina i Rodzina u Siebie to znaki opisowe aspirujące do miana sugestywnych lub wyobrażeniowych, gdzie leksem rodzina pełni funkcję wytrychu interpretacyjnego dla odbiorcy ( $w$ dwóch pierwszych ma wskazywać więzi emocjonalne, a w ostatnim materialne), by nie odczytał on znaku opatrznie do założonych celów perswazji. Rodzina w dwóch pierwszych znakach to wspólnota zamknięta, ale i odizolowana od otaczającego świata. Jeszcze mniej wiarygodnie pod tym względem wypadają znaki operatora Play z ofertą dedykowaną 4-osobowym rodzinom, które prezentuje się w zestawieniu liczbowym lub duplikuje graficznie jej członków (to zbiór jednostek bez podziału na płeć i cech indywidualnych), pozostawiając wrażenie bezproblemowej 
wymiany jednego z komponentów (przy okazji zgodne z reklamową ofertą) i braku jakiejkolwiek wspólnoty między nimi, co przeczy zarówno potocznym wyobrażeniom rodziny, jak i jej definicjom obecnym na gruncie nauki (por. definicje rodziny w naukach o polityce i administracji, naukach socjologicznych, psychologii czy teologii, gdzie obok relacji pokrewieństwa podkreśla się bliskie więzi łączące rodzinę oraz jej wspólnotowość opartą na miłości, poświęceniu i odpowiedzialności) (Szymczak, 2002, s. 163).

\section{Rodzina w reklamie telewizyjnej}

Badania frekwencji leksemów w reklamie dowodzą występowania kilku płaszczyzn tematycznych, wśród których wymienia się płaszczyznę konsumpcji (kupna-sprzedaży), płaszczyznę nieograniczonych możliwości (co ujawnia się m.in. w nadreprezentacji czasownika „móc” i jego synonimów) oraz płaszczyznę egzystencji, gdzie dom i rodzina zajmują wysokie na liście frekwencyjnej pozycje (Bończyk, 2018, s. 162). Obraz rodziny w reklamie jest właściwy przede wszystkim reklamie telewizyjnej, dlatego to ona stała się materiałem do przedstawionych w tym artykule badań.

O popularności problematyki związanej z przedstawianiem rodziny w reklamie świadczy fakt, że doczekała się ona w literaturze przedmiotu własnego określenia 'reklama rodzinna', odnoszącego się do przekazu reklamowego, „w którym bohaterowie występują w roli małżonków, rodziców, dzieci, dziadków, którzy biorą udział w prezentacji produktu" (Leszczuk-Fiedziukiewicz, 2004, s. 364). Samo określenie jest tu jednak nieprecyzyjne i znaczeniowo niezbyt adekwatne, przymiotnik „rodzinny” odnosi się bowiem do cech samej rodziny (charakterystyczny dla danej rodziny, dotyczący rodziny) lub pochodzenia jej członków (por. wyrażenie rodzinne strony ${ }^{2}$ ). Precyzyjniejsze zatem byłoby określenie tego zbioru reklam jako adresowanych do członków rodziny lub posługujących się ramą rodziny. $Z$ tego też powodu do analizy reklam jako metodologię wykorzystano właśnie lingwistyczne ujęcie ramowania - frame semantics (Fillmore, 1976, s. 20, 25; 1982, s. 111). Ramowanie będzie tu respektowane przez pryzmat definicji Fillmore'a jako rodzaj ideowego rusztowania „systemu pojęć związanych ze sobą w taki sposób, że aby zrozumieć jakiekolwiek z nich, trzeba zrozumieć całą strukturę, w której to pojęcie się zawiera" (Fillmore, 1982, s. 111).

Ramy są przywoływane w konwersacji przez poszczególne słowa (czasowniki, rzeczowniki, przymiotniki) lub ich struktury gramatyczne (składniowe), które, przywołując charakterystyczne dla ich użycia (lub związane z nimi) znaczenia, aktywują w umyśle nadawcy i odbiorcy pewne wyobrażenia stające się podstawą interpretacji materiału językowego (Ryłko-Kurpiewska, 2016, s. 189) ${ }^{3}$.

\footnotetext{
${ }^{2}$ Relacje te oddaje słownik relacyjny: Słowosieć. Pozyskano z: http://plwordnet.pwr.wroc.pl/ wordnet/cf80b744-5d16-11e9-a56b-633271de9c77 (dostęp: 06.01.2020).

${ }^{3}$ Autorka odnosi się tutaj do pojęcia w znaczeniu, jakie przypisywał mu Fillmore (1982, s. 111).
} 


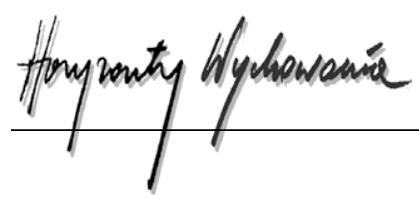

W zebranym materiale największą grupę stanowiły reklamy podstawowych produktów spożywczych, słodyczy, środków farmaceutycznych oraz oferty handlowe hipermarketów i sklepów meblarskich, których zaplanowanymi adresatami są przede wszystkim kobiety, będące zarówno decydentami, jak i nabywcami produktów w obszarze gospodarstwa domowego. Drugą grupę stanowiły reklamy kierowane do mężczyzn, promujące usługi finansowe, sprzęt RTV oraz samochody. To profilowanie adresatów odpowiadało badaniom rynku (Mindshare 2018-19://www.wirtualnemedia.pl/artykul/w-polskich-domach-decyzje-zakupowe-podejmuja-kobiety; dostęp: 20.12.2019), które ukazują wskaźniki w zakresie decyzji zakupowych podejmowanych w rodzinie przez kobiety (67\% środki farmaceutyczne, $65 \%$ podstawowe produkty spożywcze i słodycze, 59\% meble) i mężczyzn (73\% samochody, 63\% sprzęt RTV, 53\% produkty finansowe). Z kolei badanie IQS, Kids' Power 2016 (Olczyk, 2017, https://nowymarketing.pl/a/16178,dzieciocentryzm-czyli-jak-dzieci-wplywaja-na-decyzje-zakupowe-rodzicow, dostęp: 10.01.2020) wyjaśnia powody równoczesnego kierowania reklam do rodziców i dzieci: reklamy mebli kierowane zazwyczaj do matek i ich potomstwa (zgodnie z badaniem dzieci są tu współdecydentami w 34\% zakupu) lub reklamy telefonii komórkowej i sprzętu RTV (wkład w decyzje określono na 39\%) oraz samochodów (dzieci współdecydują o zakupie w 12\%) adresowane do ojców i dzieci. W zebranym materiale reklamy te stanowią jednak grupę najmniej liczną.

Rama rodziny w reklamie zawsze zależy od grupy docelowej, co łączy się z aktywowaniem różnych składników pojęcia w obrębie schematycznego wyobrażenia członków wspólnoty (ojca, matki, potomstwa), relacji do miejsca (domu, mieszkania) oraz doświadczeń użytkowników języka, które wpływają na interpretację wyrażenia pod wpływem użytych słów i ich połączeń (być, mieszkać, przebywać, wracać). Charakterystyczne jest, że w reklamach kierowanych do matek często pomija się postać ojca jako istotny składnik schematu, podobnie jak w reklamach kierowanych do ojców niejednokrotnie pomija się postać matki ${ }^{4}$. Składniki te dzięki ramowaniu nie zostają jednak utracone, gdyż ich dostępność wynika z całościowej struktury wiedzy (rodzina), prowadząc dodatkowo ku efektywniejszemu odczytowi przekazu wynikającemu z redukcji cech, które odbiorca chce w nich dostrzegać (Szczęsna, 2001, s. 137).

Z wykorzystaniem ram łączy się sposób przedstawiania postaci. W przekazach adresowanych do mężczyzn wyobrażenie ojca odpowiada typom określanym przez Martę Biercę (2019) mianem zasadniczego profesjonalisty (por. wyrażenie: głowa rodziny, rzeczowniki: szef, ambicja, sukces, czasowniki: odpowiadać, zabezpieczać), odpowiedzialnego wychowawcy (opiekować, chronić, dbać) lub dumnego kumpla (bawić się). Mężczyzna w tych przekazach ma być odpowiednikiem wyobrażonego adresata i jest zawsze bohaterem pierwszoplanowym. W reklamach kierowanych do matek to właśnie ona jest odpowiedzialna za dom, pełni funkcje opiekuńcze i wychowawcze oraz pielęgnuje

${ }^{4}$ Zdarza się również, że matka jest bohaterem drugoplanowym lub pełni funkcję znaku. W obu sytuacjach jej bierność, a równocześnie cicha aprobata dla działań męża ma konstytuować go w przedstawianej roli. 
więzi emocjonalne (ramę aktywują tu czasowniki: karmić, pielęgnować, wspierać, gotować oraz rzeczowniki: więź, macierzyństwo, kobieta). Wyobrażenie mężczyzn w tych reklamach, jeśli się pojawia, jest odpowiednikiem tzw. mężczyzny empatycznego, udomowionego, zgodnego z wizerunkiem mężczyzn w mediach dedykowanych kobietom (Lisowska-Magdziarz, 2012, s. 123). Dobrym przykładem może tu być reklama Rutinoscorbinu, gdzie mężczyzna opiekuje się dziećmi podczas choroby, zastępując matkę i tym samym spełniając jej oczekiwania.

Komunikaty odwołujące się do wyobrażeń rodziny wykorzystują przede wszystkim wiedzę odbiorców zbudowaną na podstawie wyobrażeń językowych związanych z powtarzalnością sytuacji, co łączy się z wykorzystaniem scen semantycznych jako struktur bardziej złożonych niż rama, posiadająca najczęściej charakter dwudzielny i przyczynowo-skutkowy. W ramach badanego materiału można wyróżnić następujące najczęściej powtarzalne sceny i scenariusze jako struktury wyższego rzędu, bo obejmujące dłuższą perspektywę czasową:

a) scena obiadu: przyrządzanie - spożywanie posiłku (reklamy zup, przypraw, sosów; predykaty: gotować, przyprawiać, robić, wlewać, rozpuszczać, garnek, warzywa, rosół, kostka, smak);

b) scena śniadania: budzenie - jedzenie/ picie (reklamy płatków śniadaniowych, kawy; predykaty: poranek, rano, budzić, zacząć, jeść);

c) scena Wigilii: przygotowywanie - świętowanie (reklamy słodyczy, operatorów telefonii komórkowych, hipermarketów; predykaty: choinka, dekoracje, prezenty, makowiec, karp, sałatka, zbliżać, lubić, uwielbiać, marzyć);

d) scena choroby: wystąpienie objawów choroby - leczenie (reklamy suplementów diety, leków na przeziębienie; predykaty: kaszel, gorączka, zgaga, chorować, boleć, ból, leczyć, oddychać, goić, rozkurczanie, ulga);

e) scena sprzątania: przestrzeń domu ulega zabrudzeniom, atakują ją wirusy i bakterie, które trzeba zlikwidować (reklamy środków czystości: czyścić, dezynfekować, zabijać, bakterie);

f) scena przejażdżki: wyruszanie w podróż - podróżowanie (reklamy samochodów, wycieraczek; predykaty: wsiadać, zapinać);

g) scenariusz oszczędzanie - odkładanie pieniędzy i zyskiwanie korzyści (reklamy kont oszczędnościowych; predykaty: odkładać, korzystać, zyskiwać).

Telewizyjne reklamy kierowane do rodzin wykorzystują ramowanie również w warstwie wizualnej, przywołując bliskie i wartościowane pozytywnie doświadczenia jako jednostki wiedzy. W związku z tym najczęściej eksponowanym miejscem staje się dom jako przestrzeń rodzinna i miejsca zamieszkania (aktywowany w zależności od typu produktu jako kuchnia bądź otwarty salon, rzadziej pokój dziecięcy czy przedpokój). W zależności od typu produktu dom jest miejscem, gdzie się przebywa (reklamy produktów spożywczych, sprzętu RTV) lub które się opuszcza, by następnie do niego powrócić (reklamy preparatów na przeziębienie, reklamy samochodów czy ofert finansowych), co odpowiada prototypowemu wartościowaniu domu jako locus amoenus. Trzeba też dodać, że w zależności od typu adresata dom jako miejsce podlega innej organizacji i stylistyce. 


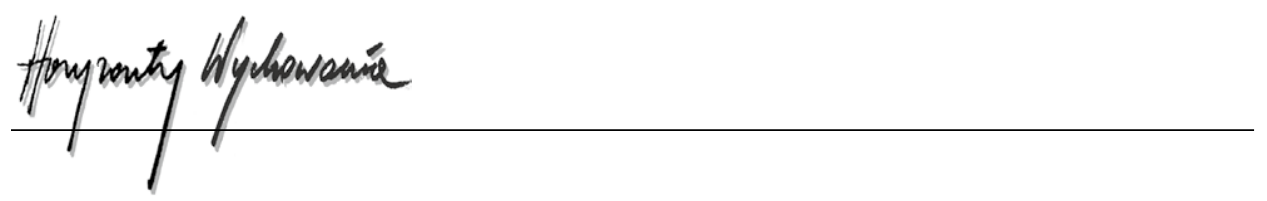

Najbardziej widocznym tego przejawem jest obraz kuchni, która w reklamach kierowanych do mężczyzn stwarza wrażenie eleganckiego minimalizmu (przestrzeń jest idealnie uporządkowana, niemalże sterylna, aranżacja pomieszczenia spójna, a stół i kuchenka idealnie czyste, co dodatkowo podkreślają zimne barwy, wyraźnie wyostrzona kolorystyka i dobór jasnego zimnego światła padającego z jednej strony). Z kolei w reklamach adresowanych do kobiet dom to miejsce, w którym panuje rozgardiasz (w sypialni jest widoczna pognieciona pościel, na stole w kuchni znajduje się zbyt wiele przedmiotów, nierzadko zobaczyć tu można rozsypane przyprawy, rozlany sos czy puste opakowania po produkcie). Ocieplenie wnętrza, odpowiadające tu potocznym wyobrażeniom ogniska domowego, dopełnia się ciepłymi nasyconymi barwami i wrażeniem światła rzucanego z wielu stron. Tym samym produkt dedykowany różnym konsumentom wpisuje się do zbioru pozytywnych wyobrażeń i codziennych doświadczeń obu grup, zyskując na wartościowaniu. Zastosowanie ramy, co należy podkreślić, służy nie tyle zapamiętywalności komunikatu czy jego zrozumiałości, ile nade wszystko „realizacji funkcji fatycznej, wartościowaniu produktów, uproszczonemu wnioskowaniu oraz przyjęciu przez odbiorcę sądów wyrażanych w reklamach zazwyczaj pośrednio" (Ryłko-Kurpiewska, 2016, s. 203).

\section{Zakończenie}

Przeprowadzone badania dowodzą, że sposób przedstawienia rodziny w znakach towarowych i reklamach telewizyjnych odpowiada najbardziej popularnym słownikowym i korpusowym znaczeniom, które uzasadniają wybór rodziny nuklearnej w reklamie w zastępstwie rodziny wielopokoleniowej. Obraz rodziny jest tu mniej zróżnicowany w zestawieniu z przekazami medialnymi o innej niż perswazyjna funkcji. Sposób przedstawienia ma wyraźnie podłoże kulturowe i stereotypowe oraz sprzyja realizacji funkcji fatycznej, wartościowaniu produktów, oferty lub producenta i wykorzystuje heurystyki, służąc przyjęciu przez odbiorcę sądów wyrażanych w komunikatach. Widocznym rysem reklam posługujących się obrazem rodziny jest wykorzystywanie codziennych doświadczeń odbiorców podyktowane typem adresata (decydenta lub decydentki zakupu) i preferowanych przez nich wartości, co łączy się z wartościowaniem postawy odbiorcy lub/i samego produktu. Wykorzystanie tradycyjnego znaczenia rodziny utrwalonego w języku i myśleniu potocznym jest modyfikowane do potrzeb zaplanowanego adresata (matki, ojca, ich potomstwa), co otwiera dyskusję nad zmieniającymi się wzorcami męskości, kobiecości i dziecięcości w języku. 


\section{BIBLIOGRAFIA}

Badanie Kids' Power (2016). Pozyskane z: http://wyborcza.biz/pieniadzeekstra/1,134263,209539 80,dzieci-decyduja-o-zakupach-nachodzi-pokolenie-jednorozcow.html (dostęp: 19.12.2019).

Bierca, M. (2019). Nowe wzory ojcostwa w Polsce. Warszawa: Wydawnictwo Borgis.

Bończyk, E. (2018). Kulturowe kody reklamy. Świat znaczeń w reklamie z perspektywy socjalizacji. Katowice: Wydawnictwo Uniwersytetu Śląskiego.

Boryś, W. (2005). Słownik etymologiczny języka polskiego. Kraków: Wydawnictwo Literackie Sp. z o.o.

CBOS (2019). Preferowane i realizowane modele życia rodzinnego. Rodzina - jej znaczenie i rozumienie. Komunikat z badań $\mathrm{nr} 46,6$.

Dubisz, S. (red.). (2003). Uniwersalny słownik języka polskiego, t. 3. Warszawa: Wydawnictwo Naukowe PWN.

Dubisz, S. (red.). (2018). Wielki słownik języka polskiego, t. 4. Warszawa: Wydawnictwo Naukowe PWN.

Dybalska, R. (1998). Pan Józef to lubi. Aida Media, 8, 51.

Fillmore, C. (1976). Frame semantics and the nature of language. Annals of the New York Academy of Sciences, 20, 25.

Fillmore, C. (1982). Frame semantics (red. zbiorowy), Linguistics in the Morning Calm: Selected Papers from SICOL-1981. Seoul: Hanshin, 111.

Handke, K. (2008). Socjologia języka. Warszawa: Wydawnictwo Naukowe PWN.

Jachnis, A. i Terelak, J. (1998), Psychologia konsumenta i reklam. Bydgoszcz: BRANTA.

Karta Praw Rodziny (1983). L'Osservatore Romano" 10 - wersja polska. Pozyskano z: http://www. srk.opoka.org.pl/srk/srk_pliki/karta.htm (dostęp: 19.12.2019).

Konstytucja Rzeczypospolitej Polskiej z dnia 2 kwietnia 1997 roku, Dz.U. 1997 Nr 78, poz. 483 ze zm. Kreja, B. (2001). Mówię więc jestem. Gdańsk: Wydawnictwo Uniwersytetu Gdańskiego.

Kurcz, I. (2000). Psychologia języka i komunikacji. Warszawa: Wydawnictwo Naukowe Scholar.

Leszczuk-Fiedziukiewicz, A. (2004). Rodzina czyli inwestycja z zyskiem. Mechanizmy perswazyjne w telewizyjnej reklamie rodzinnej. W: R. Garpiel i K. Leszczyńska (red.), Sztuka perswazji. Socjologiczne, psychologiczne i lingwistyczne uwarunkowania przekazu perswazyjnego. Kraków: NOMOS.

Lisowska-Magdziarz, M. (2012). Feniksy, łabędzie, motyle. Media i kultura transformacji. Kraków: Wydawnictwo Uniwersytetu Jagiellońskiego.

Markowski, A. (red.) (2007). Słownik poprawnej polszczyzny. Warszawa: Wydawnictwo Naukowe PWN.

Mindshare (2018-2019). Decyzyjność zakupowa w Polsce. Opis ilościowego badania rynku. Pozyskano z: https://www.wirtualnemedia.pl/artykul/w-polskich-domach-decyzje-zakupowe-podejmuja-kobiety (dostęp: 10.12.2019).

Mindshare Huddle For Good (2018). Pozyskano z: www.wirtualnemedia.pl/artykul/stosunek-do-reklam-polakow-raport (dostęp: 30.12.2019).

Narodowy Korpus Języka Polskiego. Pozyskano z: www.nkjp.uni.lodz.pl (dostęp: 10.12.2019).

Olczyk, D. (2017). Dzieciocentryzm, czyli jak dzieci wpływają na decyzje zakupowe rodziców? Pozyskano z: https://nowymarketing.pl/a/16178,dzieciocentryzm-czyli-jak-dzieci-wplywaja-na-decyzje-zakupowe-rodzicow (dostęp: 10.01.2020).

Oparski, K. (1998). Polowanie na mężczyznę. Aida Media, 9, 52.

Ryłko-Kurpiewska, A. (2016). Reklama jako sztuka powtórzeń. Gdynia: Novae Res.

Słowosieć. Pozyskano z: http://plwordnet.pwr.wroc.pl/wordnet/cf80b744-5d16-11e9-a56b633271de9c77 (dostęp: 5.01.2020).

Szczęsna, E. (2001). Poetyka reklamy. Warszawa: Wydawnictwo Naukowe PWN. 


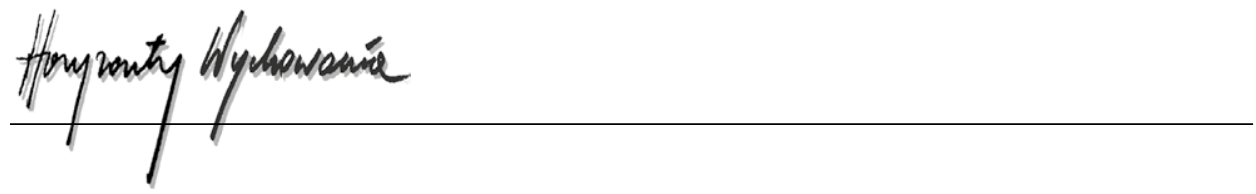

Szymczak, J. (2002). Definicje rodziny. Studia nad Rodziną, 2(11), 163.

Szymczak, M. (1981). Słownik języka polskiego, t. 3. Warszawa: PWN.

Urząd Patentowy RP. Wyszukiwarka dla znaków towarowych. Pozyskano z: regservtd.uprp.pl/ register/advancedSearch?searchMode=advanced $\& \mathrm{pn}=\& \mathrm{ap}=\& \mathrm{fd}=\& \mathrm{pd}=\& \mathrm{prd}=\& \mathrm{pa}=\& \mathrm{re}=\& \mathrm{in}=$ $\& p r=\& t i=$ rodzina\&op=\&ic= (dostęp: 19.12.2019).

Ustawa z dnia 25 lutego 1964 r. - Kodeks rodzinny i opiekuńczy, Dz.U. z 2015 r., poz. 2082, art. 146. Zboralski, M. (1995). Nomen omen, czyli jak nazwać firmę i produkt. Warszawa: Business Press. Żmigrodzki, P. (red.). (2018). Wielki słownik języka polskiego. Pozyskano z: https://wsjp.pl/index. php?id_hasla=12839\&id_znaczenia=4316275\&l=22\&ind=0 (dostęp: 10.12.2019).

\section{Copyright and License}

This article is published under the terms of the Creative Commons Attribution - NoDerivs (CC BY- ND 4.0) License http://creativecommons.org/licenses/by-nd/4.0/ 